\title{
List of biography and history published mostly in Photosynthesis Research, 1988-2008
}

\author{
Govindjee
}

Published online: 31 January 2009

(C) Springer Science+Business Media B.V. 2009

\begin{abstract}
As an outgoing Editor of the Historical Corner of Photosynthesis Research, I present here the following list of papers of historical interest for the benefit of all. The first paper I published was: Govindjee (1988) The Discovery of Chlorophyll-protein Complex by Emil L. Smith during 1937-1941. Photosynth Res 16:285-289. In order to bring to the readers this List of references on the historical papers published in this journal (and some even elsewhere), I have organized these papers under the following headings (some are arbitrarily assigned to a particular section since they may fit in more than one section): (I) biographies (that include obituaries and tributes, arranged alphabetically, with dates of birth and death); (II) recognitions of scientists (arranged alphabetically) by others; (III) personal perspectives (arranged alphabetically); (IV) historical papers (first chronologically, by the year of publication, and then alphabetically by the names of the editors); (V) special issues of Photosynthesis Research (chronologically by the year of publication and then alphabetically by the names of editors); and lastly (VI) Conferences (available reports in Photosynthesis Research).
\end{abstract}

"The firefly seems afire, the sky looks flat; Yet sky and fly are neither this nor that"

I will appreciate readers to send me (by e-mail: gov@illinois.edu) corrections, if any, and additional references from other journals.

Govindjee $(\square)$

Department of Plant Biology, University of Illinois at UrbanaChampaign, 265 Morrill Hall, 505 South Goodwin Avenue, Urbana, IL 61801, USA

e-mail: gov@illinois.edu

\section{Biographies}

George Akoyunoglou (1927-1986)

Papageorgiou GC (1987) George Akoyunoglou (19271986). Photosynth Res 11:283-286

Jan Amesz (1934-2001)

Hoff AJ, Aartsma (2002) Jan Amesz (11 March 1934-29 January 2001). Photosynth Res 71:1-4

Daniel I. Arnon (1910-1994)

Buchanan BB (1995) Introduction: the life of Daniel I Arnon. Photosynth Res 46:3-6

Buchanan BB, Carlson D (1995) Daniel I Arnon: portrayal of a research career. Photosynth Res 46:7-12

Malkin R (1995) Daniel I Arnon (1910-1994). Photosynth Res 43(2):77-80

William Arnold (1904-2001)

Herron HA (1996) About Bill Arnold, my father. Photosynth Res 48(1-2):3-7

Pearlstein RM (1996) Bill Arnold: scientist, philosopher, friend. Photosynth Res 48(1-2):9-10

Strehler BL (1996) Halcyon days with Bill Arnold. Photosynth Res 48(1-2):11-18

Mordhay Avron (1931-1991)

Malkin S, Gromet-Elhanan Z (1992) Mordhay Avron (1931-1991). Photosynth Res 31(2):71-73

Sestak Z (1992) Mordhay Avron (1931-1991). Photosynthetica 26:163-164 
Gerald T. Babcock (1946-2000)

Yocum C, Ferguson-Miller S, Blankenship R (2001) Gerald T Babcock (1946-2000). Photosynth Res 68(2):89-94

Charles Reid Barnes (1858-1910)

Gest H (2002) History of the word photosynthesis and evolution of its definition. Photosynth Res 73(1-3):7-10

Smocovitis VB (2006) One hundred years of American botany: a short history of Botanical Society of America. Am J Bot 93:942-952

John Biggins (1936-2004)

Bruce D, Sauer K (2005) John Biggins (1936-2004): his ingenuity, tenacity and humor; no-nonsense science with a big heart. Photosynth Res 85(3):261-265

Frederick Frost Blackman (1866-1947)

Briggs GE (1948) F.F. Blackman (1866-1947). Obit Notices Fellows R Soc 5(16):651-658

Steward FC, Memorial Committee (1947) In memoriam: Frederick Frost Blackman (July 25, 1866-January 30, 1947). Plant Physiol 22(3):ii-viii

Lawrence Blinks (1900-1989)

A symposium "A tribute to Lawrence R. Blinks: ions, light, and algae" was held on July 31, 2006, University of California-Chico, Botanical Society of America; Chair: Anitra Thorhaug. See abstracts at: http://www. 2006. botanyconference.org/engine/search/?func= program\&program $=110 \#$ results

Lawrence Bogorad (1921-2003)

Rodermel S, Viret JF, Krebbers E (2005) Lawrence Bogorad (1921-2003), a pioneer in photosynthesis research: a tribute. Photosynth Res 83(1):17-24

Charles Bonnet (1720-1793)

Hedges TR Jr (2007) Charles Bonnet, his life and his syndrome. Surv Ophthalmol 52(1):111-114

Rieppel O (1985) The dream of Charles Bonnet (17201793). Gesnerus 42(3-4):359-367

Jagadish C. Bose (1858-1937)

Mukherjee DC, Sen D (2007) A tribute to Sir Jagadish Chandra Bose (1858-1937). Photosynth Res 91(1): $1-10$

Jean-Marie Briantais (1936-2004)

de Kouchkovsky Y, Cerovic ZG (2005) Jean-Marie Briantais (1936-2004), a friend and a champion of interactive and integrative research. Photosynth Res 83(1):1-3
Allan H. Brown (1917-2004)

Black CC, Mayne BC (2006) Allan H Brown (19172004), editor and educator: a career of fascination with the biological roles of $\mathrm{O}_{2}$ in terrestrial life and possibly in extraterrestrial life. Photosynth Res 87(2):159-163

Warren L Butler (1925-1984)

Bishop NI (1986) Warren L Butler; a tribute to a friend and fellow scientist. Photosynth Res 10(3):147-149

Govindjee (1986) Publications of Warren L Butler on photosynthesis. Photosynth Res 10(3):151-161

Melvin Calvin (1911-1997)

Loach P (1997) A remembrance of Melvin Calvin. Photosynth Res 54(1):1-3

George Cheniae (1928-2001)

Frasch WD, Sayre RT (2001) Remembering George Cheniae, who never compromised his high standards of science. Photosynth Res 70(3):245-247

Germaine Cohen-Bazire (Stanier) (1920-2001)

Rippka R (2003) Germaine Stanier (Cohen-Bazire) 1920-2001. Arch Hydrobiol-Suppl 148:17-34

Therese M. Cotton-Uphaus (1939-1998)

Seibert M, Thurnauer M (1999) Therese Marie CottonUphaus (1939-1998). Photosynth Res 61(3):193-196

R.H. Dastur (1896-1961)

Asana RD (1961) Prof. R.H. Dastur, O.B.E. Nature 192:1128

Nicholas Theodore De Saussure (1767-1845)

Hart H (1930) Nicolas Theodore De Saussure. Plant Physiol 5(3):424-429

Don Charles DeVault (1915-1990)

Parson WW (1989) Don DeVault. A tribute on the occasion of his retirement. Photosynth Res 22(1): $11-13$

Seibert M (1991) Don Charles DeVault. Photosynth Res 28(3):95-98

Karl Egle (1912-1975)

Fock H (1976) Professor Dr. Karl Egle (1912-1975). Photosynthetica 10: unnumbered pages (in German)

Theodor W. Engelmann (1843-1909)

Drews G (2005) Contributions of Theodor Wilhelm Engelmann on phototaxis, chemotaxis, and photosynthesis. Photosynth Res 83(1):25-34 
Michael C.W. Evans (1940-2007)

Heathcote P, Nugent J (2008) Michael Charles Whitmore Evans (September 24, 1940-February 21, 2007). Photosynth Res 96(1):1-4

Agnes Faludi Daniel (1929-1986)

Garab G, Mustardy L, Demeter S (1987) Agnes Faludi Daniel (1929-1986). Photosynth Res 13:99-100

Gordon E. (Tony) Fogg (1919-2005)

Thake B (2006) Gordon Elliott (Tony) Fogg (19192005): pioneering plant physiologist and gifted writer. Photosynth Res 90(1):1-4

James Franck (1882-1964)

Rosenberg JL (2004) The contributions of James Franck to photosynthesis research: a tribute. Photosynth Res 80(1-3):71-76

Charles Stacy French (1907-1995)

Fork DC (1996) Charles Stacy French: a tribute. Photosynth Res 49(1):91-101

Fork DC (1996) Charles Stacy French (1907-1995). Photosynthetica 33:1-6

Yoshihiko Fujita (1932-2005)

Murakami A, Mimuro M (2006) Yoshihiko Fujita (1932-2005): a pioneer of photoregulation in cyanobacteria. Photosynth Res 88(1):1-5; erratum: p. 7

Hans Gaffron (1902-1979)

Homann PH (2003) Hydrogen metabolism of green algae: discovery and early research $-\mathrm{a}$ tribute to Hans Gaffron and his coworkers. Photosynth Res 76(1-3):93-103

Martin Gibbs (1922-2006)

Black CC Jr (2008) Martin Gibbs (1922-2006): pioneer of ${ }^{14} \mathrm{C}$ research, sugar metabolism \& photosynthesis; vigilant editor-in-chief of Plant Physiology; sage educator; and humanistic mentor. Photosynth Res 95(1):1-10

Black CC, Govindjee (2008) Martin Gibbs and the peaceful uses of nuclear radiation, ${ }^{14} \mathrm{C}$. Photosynth Res 99(1):63-80

Tikhon N. Godnev (1892-1982)

Virgin H, Volotovskii (1993) Tikhon N. Godnev (18921982). Photosynthetica 29:163-165

Norman E. Good (1917-1992)

Hangarter RP, Ort DR (1992) Norman E Good (19171992). Photosynth Res 34(2):245-247
David John Goodchild (1930-1989)

Anderson JM (1990) David John Goodchild. Photosynth Res 24(2):115-116

Paul R. Gorham (1918-2006)

Nozzolillo CG, Gorham H, Govindjee (2007) Paul R Gorham (April 16, 1918-November 9, 2006). Photosynth Res 92(1):3-5

Zippora Gromet-Elhanan (1931-2007)

McCarty RE (2008) Zippora Gromet-Elhanan (19312007), a passionate and fiercely dedicated scientist. Photosynth Res 96(2):117-119

David Hall (1935-1999)

Rao KK (1999) David Hall (1935-1999). Photosynth Res 62(2):117-119

Per Halldal (1922-1986)

Björn LO, Sundqvist C, Öquist G (2007) A tribute to Per Halldal (1922-1986), a Norwegian photobiologist in Sweden. Photosynth Res 92(1):7-11

Robert Hill (1899-1991)

Anderson MC (1993) Robin Hill, FRS: a Cambridge neighbor's appreciation of a great man and his hemispherical camera. Photosynthetica 28:321322

Bendall DS, Walker DA (1991) Robert (Robin) Hill (1899-1991). Photosynth Res 30(1):1-5

Goodwin J (1992) Dr Robin Hill: natural dyes. Photosynth Res 34(3):321-322

Govindjee (2001) Calvin and Hill prizes: 2001. Photosynth Res 70(3):325-328

Walker DA (2002) 'And whose bring presence'-an appreciation of Robert Hill and his reaction. Photosynth Res 73(1-3):51-54

Gábor Horváth (1944-2000)

Garab G (2000) Gábor Horváth (1944-2000). Photosynth Res 65(2):103-105

Jan Ingen-Housz (1730-1799)

Gest H (2000) Bicentenary homage to Dr Jan IngenHousz, MD (1730-1799), pioneer of photosynthesis research. Photosynth Res 63(2):183-190

Seikichi Izawa (1926-1997)

Berg S (1998) Seikichi Izawa (1926-1997). Photosynth Res 58(1):1-4 
Melvin P. Klein (1921-2000)

Britt RD, Sauer K, Yachandra VK (2000) Remembering Melvin P Klein. Photosynth Res 65(3):201-206

Elena N. Kondratieva (1925-1995)

Olson JM, Ivanovsky RN, Fuller RC (1996) Elena N Kondratieva (1925-1995). Photosynth Res 47(3): 203-205

Hugo P. Kortschak (1911-1983)

Nickell LG (1993) A tribute to Hugo P Kortschak: the man, the scientist and the discoverer of $\mathrm{C}_{4}$ photosynthesis. Photosynth Res 35(2):201-204

Alexander Abramovich Krasnovsky (1913-1993)

Karapetyan N (1993) AA Krasnovsky (1913-1993). Photosynthetica 29:481-485

Karapetyan N (1993) AA Krasnovsky (1913-1993). Photosynth Res 38(1):1-3

Julio López-Gorgé (1935-2004)

Sahrawy Barragán M (2005) A tribute to Julio LópezGorgé (1935-2004): the music in science. Photosynth Res 83(3):283-286

Henrik Lundegairdh (1888-1969)

Larkum AWD (2003) Contributions of Henrik Lundegårdh. Photosynth Res 76(1-3):105-110

Helmut Metzner (1925-1999)

Fischer-Zeh K (2000) Helmut Metzner (1925-1999). Photosynth Res 63(3):191-194

Lee McIntosh (1949-2004)

Kende H (2006) Remembering Lee McIntosh (19492004), a pioneer in the molecular biology of chloroplast and mitochondrion function. Photosynth Res 87(3):247-251

Peter Mitchell (1920-1992)

Crofts A (1993) Peter Mitchell (1920-1992). Photosynth Res 35(1):1-4

Hans Molisch (1856-1937)

Gest H (1991) The legacy of Hans Molisch (1856-1937), photosynthesis savant. Photosynth Res 30(1):49-59

Alexis Moyse (1912-1991)

Champigny ML (1992) Alexis Moyse (1912-1991). Photosynthetica 26:161-162
Jack E. Myers (1913-2006)

Brand JJ, Krogman DW, Patterson CO (2008) Jack Edgar Myers (1913-2006), an algal physiologist par excellence. Photosynth Res 96(1):9-14

André Pirson (1910-2004)

Senger H (2004) Tribute: in memory of professor Dr Dr hc André Pirson, a pioneer in photosynthesis and a dedicated academic teacher. Photosynth Res 82(2): $111-114$

John R. Quayle (1926-2006)

Kornberg HL (2006) John Rodney Quayle (1926-2006), a brilliant scientist who was also a wise and innovative academic administrator. Photosynth Res 89(2-3):59-62

Efraim Racker (1931-1991)

Nelson N (1992) Efraim Racker (1913-1991). Photosynth Res 31(3):165-166

K. Krishna Rao (1928-2006)

Cammack R (2006) K Krishna Rao-a lifetime study of ferredoxins and solar hydrogen. Photosynth Res 90(2):97-99

August Ried (1924-2004)

Strotmann H, Soeder C-J (2005) August Ried (19242004), an outstanding researcher, and artist and a dear friend. Photosynth Res 83(3):279-281

Eugene Roux (1924-2004)

Lutz M, Galmiche JM (1987) Eugene Roux (19242004). Photosynth Res 12:91-93

Samuel Ruben (1913-1943)

Gest H (2004) Samuel Ruben's contributions to research on photosynthesis and bacterial metabolism with radioactive carbon. Photosynth Res 80(1-3):77-83

Noun Shavit (1930-1997)

Aflalo C, Baum H, Chipman DM, McCarty RE, Strotmann H (1997) Noun Shavit (1930-1997). Photosynth Res 54(3):165-167

Alexander A. Shlyk (1928-1984)

Krasnovsky AA (2003) Alexander A. Shlyk (19281984). Photosynth Res 76:389-403

Krasnovsky AA, Voltovski ID, Chaika MT, Fradkin LI (1985) Alexander A. Shlyk (1928-1984). Photosynthetica 19:485-486 


\section{Gauri S. Singhal (1933-2004)}

Andley UP, Velagaleti PNR, Sen A, Tripathy BC (2005) Gauri Shankar Singhal (1933-2004): a photochemist, a photobiologist, a great mentor and a generous friend. Photosynth Res 85(2):145-148

William R. Sistrom (1927-1993)

Castenholz RW (1994) William R Sistrom (1927-1993). Photosynth Res 42(3):167-168

Stanier, Roger (1916-1982)

Ingraham JL (1982) Roger Y. Stanier (1916-1982). Arch Mikrobiol 133(1):1

Ken-ichiro Takamiya (1943-2005)

Ohta H, Masuda T, Matsuura K (2008) Ken-ichiro Takamiya (1943-2005), a gentleman and a scientist, a superb experimentalist and a visionary. Photosynth Res 97(2):115-119

Hiroshi Tamiya (1903-1986)

Sestak Z (1986) Hiroshi Tamiya (1903-1986). Photosynthetica $20: 81$

Vidyadhar G. (Pandit) Tatake (1926-2004)

Sane PV (Raj), Phondke GP (Bal) (2006) Vidyadhar Govind (Pandit) Tatake (1926-2004): an ingenious instrumentalist, an authority on thermoluminescence, and a lover of classical Indian music. Photosynth Res 89(1):49-51

Jan Bartholomeus Thomas (1907-1991)

van Ginkel G, Goedheer J (1991) Jan Bartholomeus Thomas (1907-1991). Photosynth Res 30(2-3):65-69

\section{Philip Thornber (1934-1996)}

Cogdell R (1996) Philip Thornber (1934-1996). Photosynth Res 50(1):1-3

Nathan Edward Tolbert (1919-1998)

Goyal A (2000) Ed Tolbert and his love for science: a journey from sheep ranch continues.... Photosynth Res 65(1):1-6

Cornelis Bernardus van Niel (1897-1985)

Hungate RE (1986) Cornelis Bernardus van Niel (18971985). Photosynth Res 10(1-2):139-142

Ilya Vassiliev (1959-2005)

Barry BA (2006) Ilya Vassiliev (January 12, 1959August 10, 2005). Photosynth Res 87(3):245-246
Birgit Vennesland (1913-2001)

Conn EE, Pistorius EK, Solomonson LP (2005) Remembering Birgit Vennesland (1913-2001), a great biochemist. Photosynth Res 83(1):11-16

Hemming Virgin (1918-2005)

Sundqvist C, Björn LO (2007) A tribute to Hemming Virgin (1918-2005), a Swedish pioneer in plant photobiology. Photosynth Res 92(1):13-16

E.C. Wassink (1904-1981)

Vredenberg WJ (1981) Professor Dr. E.C. Wassink (1904-1981). Photosynthetica 15:315-316

Samuel G. Wildman (1912-2004)

Tobin E (2006) Samuel Goodnow Wildman (19122004): discoverer of fraction I protein, later named Rubisco, who worked till he was 92 . Photosynth Res 88(2):105-108

Horst T. Witt (1922-2007)

Renger G (2008) Horst Tobias Witt (March 1, 1922 May 14, 2007). Photosynth Res 96(1):5-8

René Wurmser (1890-1993)

Joliot P (1996) René Wurmser (September 24, 1890November 9, 1993). Photosynth Res 48(3):321-323

\section{Recognitions}

William A. Arnold

Duysens LNM (1996) W.A. Arnold's inspiring experiments. Photosynth Res 48(1-2):25-29

Knox RS (1996) Electronic excitation transfer in the photosynthetic unit: reflections on work of William Arnold. Photosynth Res 48(1-2):35-39

Lavorel J (1996) The importance of being lucky: a tribute to William Arnold. Photosynth Res 48(1-2):31-34

Malkin S, Fork DC (1996) Bill Arnold and calorimetric measurements of the quantum requirement of photosynthesis-once again ahead of his time. Photosynth Res 48(1-2):41-46

Mauzerall D (1996) Bill Arnold's concept of solid state photosynthesis and his discoveries. Photosynth Res 48(1-2):19-23

\section{Daniel I. Arnon}

Buchanan BB, Tagawa K (1995) Perspective on Daniel I Arnon's contributions to research, 1960-1994. Photosynth Res 46(1-2):27-35 


\section{Andrew A. Benson}

Anderson JM (2007) Thylakoid membrane landscape in the sixties: a tribute to Andrew Benson. Photosynth Res 92(2):193-197

Buchanan BB, Douce R, Lichtenthaler HK (2007) Andrew A Benson. Photosynth Res 92(2):143-144

Jeffrey SW (2007) Professor Andrew A Benson: inspirational mentor. Photosynth Res 92(2):187-192

Lichtenthaler HK, Buchanan BB, Douce R (2008) Honoring Andrew Benson in Paris. Photosynth Res 92(2):181-183

\section{Olle Björkman}

Govindjee (2001) Our greetings to Olle Björkman, Christopher Field, and Alexander Glazer. Photosynth Res 70(2):241-243

\section{Warren Butler}

Govindjee, Barber J, Cramer WA, Goedheer JHC, Lavorel J, Macelle R, Zilinskas B (eds) (1986) Excitation and electron transfer in photosynthesisspecial issue-dedicated to Warren L. Butler. Photosynth Res 10:147-518

\section{Melvin Calvin}

Govindjee (2001) Calvin and Hill prizes: 2001. Photosynth Res 70(3):325-328

\section{Don Devault}

Blankenship RE, Amesz J, Holten D, Jortner J (eds) (1989) Tunneling processes in photosynthesisdedicated to Donald DeVault. Part 1. Photosynth Res 22:1-122

Blankenship RE, Amesz J, Holten D, Jortner J (eds) (1989) Tunneling processes in photosynthesisdedicated to Donald DeVault. Part 2: Photosynth Res 22:173-301

Parson WW (1989) Don Devault: a tribute on the occasion of his retirement. Photosynth Res 22(1):11-13

Louis N.M. Duysens

Amesz J, Hoff AJ, Van Gorkom HJ (eds) (1986) Current topics in Photosynthesis-double issue dedicated to Professor Louis N. M. Duysens on the occasion of his retirement. Photosynth Res 9:1-283

\section{Robert Emerson (1903-1959)}

Emerson had passed away long before 'Photosynthesis Research' came into existence, but no article has appeared thus far dedicated to him in this journal. I, however, list below three articles on him, published elsewhere.
Govindjee (2001) Lighting the path: a tribute to Robert Emerson (1903-1959). S43-001 (6 pp); available free at http://www.publish.csiro.au/?act=view_file\& file_id=SA0403744.pdf

Govindjee (2004) Robert Emerson and Eugene Rabinowitch: understanding photosynthesis. In: Hoddeson L (ed) No boundaries. University of Illinois Vignettes. University of Illinois Press, Urbana, pp 181-194

Rabinowitch E (1961) Robert Emerson (1903-1959). Biogr Mem Natl Acad Sci USA 25:112-131

\section{Christopher Field}

Govindjee (2001) Our greetings to Olle Björkman, Christopher Field, and Alexander Glazer. Photosynth Res 70(2):241-243

\section{Alexander Glazer}

Govindjee (2001) Our greetings to Olle Björkman, Christopher Field, and Alexander Glazer. Photosynth Res 70(2):241-243

\section{Govindjee}

Eaton-Rye JJ (2007) Celebrating Govindjee's 50 years in Photosynthesis Research and his 75th birthday. Photosynth Res 93(1-3):1-5

Eaton-Rye JJ (2007) Snapshots of the Govindjee lab from the late 1960s to the late 1990s, and beyond. Photosynth Res 94(2-3):153-178

Rebeiz CA, Benning C, Bohnert H, Hoober JK, Portis AR (2007) Govindjee was honored with the first lifetime achievement award, and Britta Förster and coworkers, with the first annual paper prize of Rebeiz foundation for basic research. Photosynth Res 94(1):147-151

\section{Robert Hill}

Govindjee (2001) Calvin and Hill prizes: 2001. Photosynth Res 70(3):325-328

Kamen MD (1992) Robert ('Robin') Hill: an appreciation. Photosynth Res 34(3):323-325

Krasnovsky AA (1992) Two days with Robin Hill and forty-five years with Hill reaction. Photosynth Res 34(3):327-328

Prince RC (1992) Robert Hill, FRS; his published work. Photosynth Res 34(3):329-332

Rich PR (1992) Robin Hill: a personal perspective. Photosynth Res 34(3):333-335

Walker DA (1992) Robert Hill. Photosynth Res 34(3):337-338 


\section{Jan Ingen-Housz}

Gest H (1997) A misplaced chapter in the history of photosynthesis research. The second publication (1796) on plant processes by Dr. Jan Ingen-Housz, MD, discoverer of photosynthesis, Photosynth Res 53:65-72

Gest H (2000) Bicentenary homage to Jan Ingen-Housz, pioneer of photosynthesis research. Photosynth Res 63:183-190

\section{Myroslawa Miginiac-Maslow}

Gadal P (2004) Myroslawa Miginiac-Maslow. Photosynth Res 79(3):229-230

Jacquot J-P (2004) Comments on the contributions of Myroslawa Miginiac-Maslow and Peter Schürmann to the light-dependent redox regulation of choloroplastic enzymes. Photosynth Res 79(3):231-232

\section{Eugene I. Rabinowitch (1898-1973)}

Bannister TT (1972) The careers and contributions of Eugene Rabinowitch. Biophys J 12(7):707-718

Brody SS (1995) We remember Eugene. Photosynth Res 43(1):67-74

Govindjee (2004) Robert Emerson and Eugene Rabinowitch: understanding photosynthesis. In: Hoddeson L (ed) No boundaries. University of Illinois Vignettes. University of Illinois Press, Urbana, pp 181-194

Rabinowitch A (2005) Founder and father. Bull At Sci 61(1):30-37

Rotblatt J (2000) Fifty Pugwash conferences: a tribute to Eugene Rabinowitch. Available online at: http:// www.pugwash.org/reports/pac/pac256/rotblat.htm

\section{Kimiyuki Satoh}

Enami I, Shen J-R (2008) A brief introduction of Kimiyuki Satoh. Photosynth Res 98(1-3):7-11

\section{Ken-ichiro Takamiya (1943-2005)}

Ohta H, Masuda T, Matsuura K (2008) Professor Kenichiro Takamiya (1943-2005) gentleman \& a scientist, a superb experimentalist and a visionary. Photosynth Res 97(2):115-119

\section{Peter Schürmann}

Buchanan BB (2004) Peter Schürmann. Photosynth Res 79(3):227-228

Jacquot J-P (2004) Comments on the contributions of Myroslawa Miginiac-Maslow and Peter Schürmann to the light-dependent redox regulation of choloroplastic enzymes. Photosynth Res 79(3):231-232

\section{Emil L. Smith}

Govindjee (1988) The discovery of chlorophyll-protein complex by Emil L. Smith during 1937-1941. Photosynth Res 16:285-289

Thomas J. Wydrzynski

Govindjee (2008) Recollections of Thomas John Wydrzynski. Photosynth Res 98(1-3):13-31

\section{Charles F. Yocum}

Siedow JN (2002) A biographical sketch of Charles F Yocum: "it's the biochemistry, stupid." Photosynth Res 72(2):123-130

\section{Personal perspectives}

Akazawa T (1994) Reminiscences, collaborations and reflections. Photosynth Res 46(1-2):93-113

Arnold WA (1991) Experiments. Photosynth Res 27(2):73-82

Barber J (2004) Engine of life and big bang of evolution: a personal perspective. Photosynth Res 80(1-3): 137-155

Benson AA (2002) Paving the path. Annu Rev Plant Biol 53:1-25

Calvin M (1989) Forty years of photosynthesis and related activities. Photosynth Res 21(1):1-16

Chance B (1991) Optical method. Annu Rev Biophys Biophys Chem 20:1-28

Clayton RK (1988) Memories of many lives. Photosynth Res 19(3):205-224

Devault D (1989) Tunneling enters biology. Photosynth Res 22(1):5-10

Drews G (1996) Forty-five years of developmental biology of photosynthetic bacteria. Photosynth Res 48:325-352

Duysens LNM (1989) The discovery of the two photosynthetic systems: a personal account. Photosynth Res 21(2):61-79

Feher G (1998) Three decades of research in bacterial photosynthesis and the road leading to it: a personal account. Photosynth Res 55(1):1-40

Feher G (2002) My road to biophysics: picking flowers on the path to photosynthesis. Annu Rev Biophys Biomol Struct 31:1-44

Forti G (1999) Personal recollections of 40 years in photosynthesis research. Photosynth Res 60(2-3): 99-110

French CS (1979) Fifty years of photosynthesis. Annu Rev Plant Physiol 30:1-26 
Frenkel AW (1993) Recollections. Photosynth Res 35(2):103-116

Fujita Y (1997) A study on the dynamic features of photosystem stoichiometry: accomplishments and problems for future studies. Photosynth Res 53(2-3):83-93

Fuller RC (1999) Forty years of microbial photosynthesis research: where it came from and what it led to. Photosynth Res 62(1):1-29

Gaffron H (1969) Resistance to knowledge. Annu Rev Plant Physiol 20:1-40

Gerhart D (1996) Forty-five years of developmental biology of photosynthetic bacteria. Photosynth Res 48(3):325-352

Gest H (1994) A microbiologist's odyssey: bacterial viruses to photosynthetic bacteria. Photosynth Res 40(2):129-146

Gest H (1994) Discovery of the heliobacteria. Photosynth Res 41(1):17-21

Gest H (1999) Memoir of a 1949 railway journey with photosynthetic bacteria. Photosynth Res 61(1):91-96

Gibbs M (1999) Educator and editor. Annu Rev Plant Physiol Plant Mol Biol 50:1-25

Good NE (1986) Confessions of a habitual skeptic. Annu Rev Plant Physiol 37:1-22

Gunsalus IC (1984) Learning. Annu Rev Microbiol 38:1-26

Hatch MD (Hal) (1992) I can't believe my luck. Photosynth Res 33(1):1-14

Hill R (1975) Days of visual spectroscopy. Annu Rev Plant Physiol 26:1-11

Jagendorf AT (1998) Chance, luck and photosynthesis research: an inside story. Photosynth Res 57(3):215-229

Joliot P (1993) Earlier researches on the mechanism of oxygen evolution: a personal account. Photosynth Res 38(3):214-223

Kamen MD (1986) A cupful of luck, a pinch of sagacity. Annu Rev Biochem 55:1-34

Kamen MD (1989) Onward into a fabulous half-century. Photosynth Res 21(3):137-144 [Also see Kauffman GB (2002) Martin D. Kamen (1913-2002), nuclear scientist and biochemist. Chem Educ 7:304-308]

Katoh S (1995) The discovery and function of plastocyanin: a personal account. Photosynth Res 43(3):177-189

Katz JJ (1990) Green thoughts in a green shade. Photosynth Res 26(3):143-160

Krasnovsky AA (1992) Excited chlorophyll and related problems. Photosynth Res 33:177-193

Krogmann DW (2000) The golden age of biochemical research in photosynthesis. Photosynth Res 63(2):109-121

Menke W (1990) Retrospective of a botanist. Photosynth Res 25(2):77-82

Myers J (1996) Country boy to scientist. Photosynth Res 50(3):195-208
Myers J (2002) In one ear and out the other. Photosynth Res 73(1-3):21-28

Ochoa S (1980) The pursuit of a hobby. Annu Rev Biochem 49:1-30

Olson JM (1994) Reminiscence about 'Chloropseudomonas ethylicum' and the FMO-protein. Photosynth Res 41(1):3-5

Pierson BK (1994) Reflections on Chloroflexux. Photosynth Res 41(1):7-15

Pirson A (1994) Sixty years in algal physiology and photosynthesis. Photosynth Res 40(3):207-221

San Pietro A (2008) Memories: from protein synthesis to photosynthesis. Photosynth Res 96(3):185-199

Shen Y (1994) Dynamic approaches to the mechanism of photosynthesis. Photosynth Res 39(1):1-13

Stanier RY (1980) The journey, not the arrival matters. Annu Rev Microbiol 34:1-48

Sweeney BM (1987) Living in the golden age of biology. Annu Rev Plant Physiol 38:1-9

Tamiya H (1966) Synchronous cultures of algae. Annu Rev Plant Physiol 17:1-21

Thornber JP (1995) Thirty years of fun with antenna pigment-proteins and photochemical reaction centers: a tribute to the people who have influenced my career. Photosynth Res 44(1-2):3-22

Tolbert NE (1997) The C2 oxidative photosynthetic cycle. Annu Rev Plant Physiol Plant Mol Biol 48:1-25

Van Niel CB (1967) The education of a microbiologist: some reflections. Annu Rev Microbiol 21:1-30

Vennesland B (1981) Recollections and small confessions. Annu Rev Plant Physiol 32:1-48

Walker DA (1997) 'Tell me where all the past years are'. Photosynth Res 51:1-26

Warburg O (1964) Prefatory chapter. Annu Rev Biochem 33:1-14

Weber G (1990) Whither biophysics. Annu Rev Biophys 19:1-6

Witt HT (1991) Functional mechanism of water splitting photosynthesis. Photosynth Res 29(2):55-77

Zelitch I (2001) Travels in a world of small science. Photosynth Res 67(3):157-176

\section{Historical papers}

\section{7}

Benning C (2007) Questions remaining in sulfolipid biosynthesis: a historical perspective. Photosynth Res 92(2):199-203

Block MA, Douce R, Joyard J, Rolland N (2007) Chloroplast envelop membranes: a dynamic interface between plastids and the cytosol. Photosynth Res 92(2):225-244 
Buchanan BB (2007) Thioredoxin: an unexpected meeting place. Photosynth Res 92(2):145-148

Govindjee, Yoo H (2007) The International Society of Photosynthesis Research (ISPR) and its associated international congress on photosynthesis (ICP) a pictoral report. Photosynth Res 91:95-106

Höxtermann E (2007) A comment on Warburg's early understanding of biocatalysis. Photosynth Res 92(1):121-127

Nickelsen K (2007) Otto Warburg's first approach to photosynthesis. Photosynth Res 92(1):109-120

Portis AR Jr, Parry MAJ (2007) Discoveries in Rubisco (Ribulose 1,5-bisphosphate carboxylase/oxygenase): a historical perspective. Photosynth Res 94(1): 121-143

Trebst A (2007) Inhibitors in the functional dissection of the photosynthetic electron transport system. Photosynth Res 92(2):217-224

Wada H, Murata N (2007) The essential role of phosphatidylglycerol in photosynthesis. Photosynth Res 92(2):205-215

Walker DA (2007) From Chlorella to chloroplasts: a personal note. Photosynth Res 92(2):181-185

\section{6}

Forti G, Agostiano A, Barbato R, Bassi R, Brugnoli E, Finazzi G, Garlaschi FM, Jennings RC, Melandri BA, Trotta M. Venturoli G, Zanetti G, Zannoni D, Zucchelli G (2006) Photosynthesis Research in Italy: a review. Photosynth Res 88(3):211-240

Giacometti GM, Giacometti G (2006) Twenty years of biophysics of photosynthesis in Padova, Italy (19842005): a tale of two brothers. Photosynth Res 88(3): 241-258

Gorham PR, Nozzolillo CG (2006) Photosynthesis research in Canada from 1945 to the early 1970s. Photosynth Res 88(1):83-100

Govindjee (2006) Celebrating 20 years of historical papers in photosynthesis research. Photosynth Res 87(2):151-158

Zeinalov Y (2006) A brief history of the investigations on photosynthesis in Bulgaria. Photosynth Res 88(2):195-204

\section{5}

Williams RJP (2005) The discovery of the nature of ferredoxin in photosystems: a recollection. Photosynth Res 85(2):247-250

\section{4}

Allen JP (2004) My daily constitutional in Martinsried. Photosynth Res 80(1-3):157-163
Bauer C (2004) Regulation of photosystem synthesis in Rhodobacter capsulatus. Photosynth Res 80(1-3): 353-360

Bendall DS (2004) The unfinished story of cytochrome $f$. Photosynth Res 80(1-3):265-276

Camm EL, Green BR (2004) How the chlorophyll-proteins got their names. Photosynth Res 80(1-3):189-196

Chance B (2004) The stopped-flow method and chemical intermediates in enzyme reactions-a personal essay. Photosynth Res 80(1-3):387-400

Cogdell RJ, Hashimoto H, Gardiner AT (2004) Purple bacterial light-harvesting complexes: from dreams to structures. Photosynth Res 80(1-3):173-179

Cramer WA (2004) Ironies in photosynthetic electron transport: a personal perspective. Photosynth Res 80(1-3):293-305

Crofts AR (2004) The Q-cycle-a personal perspective. Photosynth Res 80(1-3):223-243

Dilley RA (2004) On why thylakoids energize ATP formation using either delocalized or localized proton gradients $-\mathrm{a} \mathrm{Ca}^{2+}$ mediated role in thylakoid stress responses. Photosynth Res 80(1-3):245-263

Ellis RJ (2004) From chloroplasts to chaperones: how one thing led to another. Photosynth Res 80(1-3): 333-343

Fajer J (2004) Chlorophyll chemistry before and after crystals of photosynthetic reaction centers. Photosynth Res 80(1-3):165-172

Fromme P, Mathis P (2004) Unraveling the photosystem I-reaction center: a history, or the sum of many efforts. Photosynth Res 80(1-3):109-124

Gest H, Blankenship RE (2004) Time line of discoveries: anoxygenic bacterial photosynthesis. Photosynth Res 80(1-3):59-70

Ghosh AK (2004) Passage of a young Indian physical chemist through the world of photosynthesis research at Urbana, Illinois, in the 1960s: a personal essay. Photosynth Res 80(1-3):427-437

Govindjee, Krogmann D (2004) Discoveries in oxygenic photosynthesis (1727-2003): a perspective. Photosynth Res 80(1-3):15-57

Govindjee, Allen JF, Beatty JT (2004) Celebrating the millennium: historical highlights of photosynthesis research, part 3. Photosynth Res 80(1-3):1-13

Hangarter RP, Gest H (2004) Pictorial demonstrations of photosynthesis. Photosynth Res 80(1-3):421-425

Hauska G (2004) The isolation of a functional cytochrome $b 6 f$ complex: from lucky encounter to rewarding experiences. Photosynth Res 80(1-3):277-291

Jensen RG (2004) Activation of rubisco controls $\mathrm{CO}_{2}$ assimilation in light: a perspective on its discovery. Photosynth Res 82(2):187-193 
Junge W (2004) Protons, proteins and ATP. Photosynth Res 80(1-3):197-221

Melis A, Happe T (2004) Trails of green alga hydrogen research-from Han Gaffron to new frontiers. Photosynth Res 80(1-3):401-409

Olson JM (2004) The FMO protein. Photosynth Res 80(1-3):181-187

Olson JM, Blankenship RE (2004) Thinking about the evolution of photosynthesis. Photosynth Res 80(1-3): 373-386

Shin M (2004) How is ferredoxin-NADP reductase involved in the NADP photoreduction of chloroplasts? Photosynth Res 80(1-3):307-313

Tabita FR (2004) Research on carbon dioxide fixation in photosynthetic microorganisms (1971-present). Photosynth Res 80(1-3):315-332

Wildman SG, Hirsch AM, Kirchanski SJ, Spencer D (2004) Chloroplasts in living cells and the string-ofgrana concept of chloroplast structure revisited. Photosynth Res 80(1-3):345-352

Witt HT (2004) Steps on the way to building blacks, topologies, crystals and X-ray structural analysis of photosystems I and II of water-oxidizing photosynthesis. Photosynth Res 80(1-3):85-107

Woese CR (2004) The archaeal concept and the world it lives in: a retrospective. Photosynth Res 80(1-3): 361-372

Wydrzynski TJ (2004) Early indications for manganese oxidation state changes during photosynthetic oxygen production: a personal account. Photosynth Res 80(1-3):125-135

Xiong L, Sayre RT (2004) Engineering the chloroplast encoded proteins of Chlamydomonas. Photosynth Res 80(1-3):411-419

\section{3}

Adir N, Zer H, Shochat S, Ohad I (2003) Photoinhibitiona historical perspective. Photosynth Res 76(1-3): 343-370

Albertsson P-A (2003) The contribution of photosynthetic pigments to the development of biochemical separation methods: 1990-1980. Photosynth Res 76(1-3):217-225

Armitage JP, Hellingwerf KJ (2003) Light-induced behavioral responses ('phototaxis') in prokaryotes. Photosynth Res 76(1-3):145-155

Bassham JA (2003) Mapping the carbon reduction cycle: a personal retrospective. Photosynth Res 76(1-3): 35-52

Belyaeva OB (2003) Studies of chlorophyll biosynthesis in Russia. Photosynth Res 76(1-3):405-411
Black CC, Osmond CB (2003) Crassulacean acid metabolism photosynthesis: 'working the night shift.' Photosynth Res 76(1-3):329-341

Bogorad L (2003) Photosynthesis research: advances through molecular biology-the beginnings, 19751980s and on. Photosynth Res 76(1-3):13-33

Borisov A (2003) The beginnings of research on biophysics of photosynthesis and initial contributions made by Russian scientists to its development. Photosynth Res 76(1-3):413-426

Daldal F, Deshmukh M, Prince RC (2003) Membraneanchored cytochrome $c$ as an electron carrier in photosynthesis and respiration: past, present and future of an unexpected discovery. Photosynth Res 76(1-3):127-134

Delosme R (2003) On some aspects of photosynthesis revealed by photoacoustic studies: a critical evaluation. Photosynth Res 76(1-3):289-301

Demmig-Adams B (2003) Linking the xanthophyll cycle with thermal energy dissipation. Photosynth Res 76(1-3):73-80

Govindjee, Beatty JT, Gest H (2003) Celebrating the millennium-historical highlights of photosynthesis research, part 2. Photosynth Res 76(1-3):1-11

Grossman AR (2003) A molecular understanding of complementary chromatic adaptation. Photosynth Res 76(1-3):207-215

Gupta RS (2003) Evolutionary relationships among photosynthetic bacteria. Photosynth Res 76(1-3): 173-183

Joliot P (2003) Period-four oscillations of the flashinduced oxygen formation in photosynthesis. Photosynth Res 76(1-3):65-72

Joliot P, Joliot A (2003) Excitation transfer between photosynthetic units: the 1964 experiment. Photosynth Res 76(1-3):241-245

Katoh S (2003) Early research on the roles of plastocyanin in photosynthesis. Photosynth Res 76(1-3):255-261

Klimov VV (2003) Discovery of pheophytin function in the photosynthetic energy conversion as the primary electron acceptor of photosystem II. Photosynth Res 76(1-3):247-253

Krasnovsky AA Jr (2003) Chlorophyll isolation, structure and function: major landmarks of the early history of research in the Russian empire and the Soviet Union. Photosynth Res 76(1-3):389-403

Kuang T-Y, Xu C, Li L-B, Shen Y-K (2003) Photosynthesis research in the People's Republic of China. Photosynth Res 76(1-3):451-458

Madigan MT (2003) Anoxygenic phototrophic bacteria from extreme environments. Photosynth Res 76(1-3): 157-171 
Meyer TE, Cusanovich MA (2003) Discovery and characterization of electron transfer proteins in the photosynthetic bacteria. Photosynth Res 76(1-3): 111-126

Miyachi S, Iwasaki I, Shiraiwa Y (2003) Historical perspective on microalgal and cyanobacterial acclimation to low- and extremely high- $\mathrm{CO}_{2}$ conditions. Photosynth Res 77(2-3):139-153

Ogawa T (2003) Physical separation of chlorophyllprotein complexes. Photosynth Res 76(1-3):227-232

Ogren WL (2003) Affixing the O to rubisco: discovering the source of photorespiratory glycolate and its regulation. Photosynth Res 76(1-3):53-63

Ormerod J (2003) 'Every dogma has its day': a personal look at carbon metabolism in photosynthetic bacteria. Photosynth Res 76(1-3):135-143

Papageorgiou GC (2003) Photosynthesis research in Greece: a historical snapshot (1960-2001). Photosynth Res 76(1-3):427-433

Parson WW (2003) Electron donors and acceptors in the initial steps of photosynthesis in purple bacteria: a personal account. Photosynth Res 76(1-3):81-92

Raghavendra AS, Sane PV, Mohanty P (2003) Photosynthesis research in India: transition from yield physiology into molecular biology. Photosynth Res 76(1-3):435-450

Renger G (2003) Apparatus and mechanism of photosynthetic oxygen evolution: a personal perspective. Photosynth Res 76(1-3):269-288

Satoh K (2003) The identification of the photosystem II reaction center: a personal story. Photosynth Res 76(1-3):233-240

Schröder WP, Kieselbach T (2003) Update on chloroplast proteomics. Photosynth Res 78(3):181-193

Seibert M, Wasielewski MR (2003) The isolated photosystem II reaction center: first attempts to directly measure the kinetics of primary charge separation. Photosynth Res 76(1-3):263-268

Staehelin LA (2003) Chloroplast structure: from chlorophyll granutes to supra-molecular architecture of thylakoid membranes. Photosynth Res 76(1-3):185196

Sugiura M (2003) History of chloroplast genomics. Photosynth Res 76(1-3):371-377

Tandeau de Marsac N (2003) Phycobiliproteins and phycobilisomes: the early observations. Photosynth Res 76(1-3):197-205

Vass I (2003) The history of photosynthetic thermoluminescence. Photosynth Res 76(1-3):303-318

Vernon LP (2003) Photosynthesis and the Charles F Kettering research laboratory. Photosynth Res 76(1-3): 379-388
Walker DA (2003) Chloroplasts in envelopes: $\mathrm{CO}_{2}$ fixation by fully functional intact chloroplasts. Photosynth Res 76(1-3):319-327

\section{2}

Allen JF (2002) Plastoquinone redox control of chloroplast thylakoid protein phosphorylation and distribution of excitation energy between photosystems: discovery, background, implication. Photosynth Res 73(1-3):139-148

Amesz J, Neerken S (2002) Excitation energy trapping in anoxygenic photosynthetic bacteria. Photosynth Res 73(1-3):73-81

Anderson JM (2002) Changing concepts about the distribution of photosystems I and II between grana-appressed and stroma-exposed thylakoid membranes. Photosynth Res 73(1-3):157-164

Beatty JT (2002) On the natural selection and evolution of the aerobic phototrophic bacteria. Photosynth Res 73(1-3): 109-114

Bennoun P (2002) The present model for chlororespiration. Photosynth Res 73(1-3):273-277

Benson AA (2002) Following the path of carbon in photosynthesis: a personal story. Photosynth Res 73(1-3):29-49

Brody SS (2002) Fluorescence lifetime, yield, energy transfer and spectrum in photosynthesis, 1950-1960. Photosynth Res 73(1-3):127-132

Buchanan BB, Schürmann P, Wolosiuk RA, Jacquot J-P (2002) The ferredoxin/thioredoxin system: from discovery to molecular structures and beyond. Photosynth Res 73(1-3):215-222

Clayton RK (2002) Research on photosynthetic reaction centers from 1932 to 1987. Photosynth Res 73(1-3): 63-71

Delosme R, Joliot P (2002) Period four oscillations in chlorophyll a fluorescence. Photosynth Res 73(1-3): 165-168

Drews G, Niederman RA (2002) Membrane biogenesis in anoxygenic photosynthetic prokaryotes. Photosynth Res 73(1-3):87-94

Gest H (2002) History of the word photosynthesis and evolution of its definition. Photosynth Res 73(1-3): $7-10$

Gest H (2002) Photosynthesis and phage: early studies on phosphorus metabolism in photosynthetic microorganisms with ${ }^{32} \mathrm{P}$, and how they led to the serendipic discovery of ${ }^{32} \mathrm{P}$-decay suicide of bacteriophage. Photosynth Res 74(3):331-339

Govindjee, Krogmann DW (2002) A list of personal perspectives with selected quotations, along with lists of tributes, historical notes, Nobel and Kettering 
awards related to photosynthesis. Photosynth Res 73(1-3):11-20

Govindjee, Sestak Z, Peters WR (2002) The early history of "Photosynthetica", "Photosynthesis Research", and their publishers. Photosynthetica 40(1):1-11

Hatch MD (2002) $\mathrm{C}_{4}$ photosynthesis: discovery and resolution. Photosynth Res 73(1-3):251-256

Heber U (2002) Irrungen, Wirrungen? The Mehler reaction in relation to cyclic electron transport in C3 plants. Photosynth Res 73(1-3):223-231

Heldt H-W (2002) Three decades in transport business: studies of metabolite transport in chloroplasts-a personal perspective. Photosynth Res 73(1-3):265-272

Homann PH (2002) Chloride and calcium in photosystem II: from effects to enigma. Photosynth Res 73(1-3): 169-175

Jagendorf AT (2002) Photophosphorylation and the chemiosmotic perspective. Photosynth Res 73(1-3): 233-241

Kaplan S (2002) Photosynthesis genes and their expression in Rhodobacter sphaeroides 2.4.1: a tribute to my students and associates. Photosynth Res 73(1-3): 95-108

Ke B (2002) P430: a retrospective, 1971-2001. Photosynth Res 73(1-3):207-214

de Kouchkovsky Y (2002) The laboratory of photosynthesis and its successors at Gif-sur-Yvette, France. Photosynth Res 73(1-3):295-303

Lewin RA (2002) Prochlorophyta-a matter of class disctinctions. Photosynth Res 73(1-3):59-61

Ludden PW, Roberts GP (2002) Nitrogen fixation by photosynthetic bacteria. Photosynth Res 73(1-3): 115-118

Marrs BL (2002) The early history of the genetics of photosynthetic bacteria: a personal account. Photosynth Res 73(1-3):55-58

Mimuro M (2002) Visualization of excitation energy transfer processes in plants and algae. Photosynth Res 73(1-3):133-138

Nelson N, Ben-Shem A (2002) Photosystem I reaction center: past and future. Photosynth Res 73(1-3):193206

Pearlstein RM (2002) Photosynthetic exciton theory in the 1960s. Photosynth Res 73(1-3):119-126

Porra RJ (2002) The chequered history of the development and use of simultaneous equations for the accurate determination of chlorophylls $a$ and $b$. Photosynth Res 73(1-3):149-156

Portis AR Jr, Salvucci ME (2002) The discovery of rubisco activase-yet another story of serendipity. Photosynth Res 73(1-3):257-264

Rochaix J-D (2002) The three genomes of Chlamydomonas. Photosynth Res 73(1-3):285-293
Shestakov SV (2002) Gene-targeted and site-directed mutagenesis of photosynthesis genes in Cyanobacteria. Photosynth Res 73(1-3):279-284

Stemler AJ (2002) The bicarbonate effect, oxygen evolution, and the shadow of Otto Warburg. Photosynth Res 73(1-3):177-183

Van Rensen JJS (2002) Role of bicarbonate at the acceptor side of photosystem II. Photosynth Res 73(1-3):185-192

Verméglio A (2002) The two-electron gate in photosynthetic bacteria. Photosynth Res 73(1-3):83-86

Walker DA (2002) 'And whose bright presence'-an appreciation of Robert Hill and his reaction. Photosynth Res 73(1-3):51-54

Wildman SG (2002) Along the trail from fraction I protein to rubisco (ribulose bisphosphate carboxylaseoxygenase). Photosynth Res 73(1-3):243-250

2000

Govindjee (2000) Milestones in photosynthesis research. In: Younis M, Pathre U, Mohanty P (eds) Probing photosynthesis. Taylor \& Francis, London, pp 9-39

1999

Govindjee (1999) On the requirement of minimum number of four versus eight quanta of light for the evolution of one molecule of oxygen in photosynthesis: a historical note. Photosynth Res 59(2-3): 249-254

\section{8}

Feher G (1998) Light reflections III. Photosynth Res 55(2-3):375-378

\section{7}

Dutton HJ (1997) Carotenoid-sensitized photosynthesis: quantum efficiency, fluorescence and energy transfer. Photosynth Res 52(2):175-185

Walker DA (1997) 'Tell me where all past years are.' Photosynth Res 51(1):1-26

\section{5}

Arnon DI (1995) Divergent pathways of photosynthetic electro transfer: the autonomous oxygenic and anoxygenic photosystems. Photosynth Res 46(1-2): 47-71

Epstein E (1995) Photosynthesis, inorganic plant nutrition, solutions, and problems. Photosynth Res 46(1-2): 37-39

Frenkel AW (1995) Photosynthetic phosphorylation. Photosynth Res 46(1-2):73-77

Jukes TH (1995) Mineral nutrition of plants. Photosynth Res 46(1-2):13-15 
Trebst A, Depka B (1995) Polyphenol oxidase and photosynthesis research. Photosynth Res 46(1-2):41-44

Walker DA (1995) One thing leading to another. Photosynth Res 46(1-2):45-46

Whatley FR (1995) Photosynthesis by isolated chloroplasts: the early work in Berkeley. Photosynth Res 46(1-2):17-26

\section{4}

Myers J (1994) The 1932 experiments. Photosynth Res 40(3):303-310

\section{3}

Cheniae GM (1993) A recollection of the development of the Kok-Joliot model for photosynthetic oxygen evolution. Photosynth Res 38(3):225-227

Gest H (1993) History of concepts of the comparative biochemist of oxygenic and anoxygenic photosyntheses. Photosynth Res 35(1):87-96

Huzisige H, Ke B (1993) Dynamics of the history of photosynthesis research. Photosynth Res 35(1): 185-209

\section{2}

Hill DJ (1992) An overlooked symbiosis. Photosynth Res 34(3):339-340

\section{0}

Kooten O, Snel JFH (1990) The use of chlorophyll fluorescence nomenclature in plant stress physiology. Photosynth Res 25(3):147-150

\section{8}

Gest H (1988) Sun-beams, cucumbers, and purple bacteria. Historical milestones in early studies of photosynthesis revisited. Photosynth Res 19(3):287-308

Govindjee (1988) Growth of Photosynthesis Research: 1980-1986. Photosynth Res 15(3):193-194

\section{Special issues}

\section{8}

Cogdell R, Mullineaux C (eds) (2008) Photosynthetic light harvesting. Photosynth Res 95(2-3):117-371

Gunner MR (ed) (2008) Computational analysis of photosynthetic systems.Photosynth Res 97(1):1-114

Allakhverdiev SI, Klimov VV, Nagata T, Nixon P, Shen J-R (eds)(2008) Recent perspectives of photosystem II: structure, function and dynamics-in honour of Kimiyuki Satoh and Thomas Wydrzynski. Photosynth Res 98(1-3):1-700

\section{7}

Buchanan BB, Douce R, Lichtenthaler HK (eds) (2007) A tribute to Andrew A. Benson. Photosynth Res 92(2):143-271

Putnam-Evans C, Barry B (eds) (2007) Photosynthetic water oxidation. Photosynth Res 92(3):273-425

Eaton-Rye JJ (ed) (2007) Govindjee special issue: part A-celebrating Govindjee's 50 years in photosynthesis research and his 75 th birthday. Photosynth Res 93(1-3):1-244

Eaton-Rye JJ (ed) (2007) Govindjee special issue: part B-celebrating Govindjee's 50 years in photosynthesis research and his 75 th birthday. Photosynth Res 94(2-3):153-466

\section{5}

Carpentier R, Allakhverdiev SI, Aro EM, Brudvig G, Diner BA, Knaff DB, Satoh K, Wydrzynski TJ (eds) (2005) Photosynthesis and the post-genomic era: from biophysics to molecular biology, a path in the research of photosystem II. Photosynth Res 84(1-3): $1-372$

\section{4}

Allen JP, Knaff DB (eds) (2004) Structural biology of proteins from photosynthetic organisms. Photosynth Res 81(3):205-348

Buchanan BB, Knaff DB, Jacquot JP (eds) (2004) Plant thioredoxins and related proteins. Photosynth Res 79(3):225-373

Sayre RT, Hippler M (eds) (2004) Molecular genomics of the Chlamydomonas chloroplast. Photosynth Res 82(3):201-354

\section{3}

Burnap RL, Vermaas WFJ (eds) (2003) Proteomics. Photosynth Res 78(3):179-302

\section{2}

Beale SI (ed) (2002) Tetrapyrrole photoreceptors in photosynthetic organisms. Photosynth Res 74(2):95-233

Govindjee, Gest H (eds) (2002) Celebrating the millennium-historical highlights of photosynthesis research, Part 1. Photosynth Res 73(1-3):1-308

Miller M, Aartsma TJ, Blankenship RE (eds) (2002) Special issue in honour of Jan Amesz: green and heliobacteria. Photosynth Res 71(1-2):vii+ 1-183

\section{1}

Berry JA, Field CB, Grossman AR (eds) (2001) Special issue in honour of Olle Björkman: plants and their light environment. Photosynth Res 67(1-2):1-156 
Mackenzie C, Kaplan S (eds) (2001) Genomics. Photosynth Res 70(1):1-127

Bassi R, Cinque G (eds) (2001) Tetrapyrrole photoreceptors in plants and algae. Photosynth Res 64(2-3): iii $+1-280$

\section{0}

Kramer DM (ed) (2000) Emerging techniques in Photosynthesis Research. Photosynth Res 66(1-2):1-158

\section{8}

Breton J, Nabedryk E, Verméglio A (eds) (1998) Reaction centers of photosynthetic purple bacteria: structure, spectroscopy, dynamics. Photosynth Res 55(2-3):117-384

\section{7}

Bauer CE (ed) (1997) Symposium in print: diversity, genetics, and physiology of photosynthetic prokaryotes in honor of the 75th birthday of Howard Gest. Photosynth Res 53(1):1-79

Mimuro M, Gantt E, Bryant DA (eds) (1997) Molecular approaches to light acclimation from Cyanobacteria to higher plants. Photosynth Res 53(2-3):81-266

\section{6}

Govindjee, Knox RS, Amesz J (eds) (1996) Special issue dedicated to William A Arnold: photosynthetic unit: antenna and reaction centers. Photosynth Res 48(1-2): $1-319$

\section{5}

Cogdell R, Nechusthtai R, Malkin R (eds) (1995) Structure, function and biogenesis of chlorophyllprotein complexes. Photosynth Res 44(1-2):1-219

Melis A, Buchanan BB (eds) (1995) A tribute to Daniel I Arnon. Photosynth Res 46(1-2):1-377

\section{4}

Falkowski PG, Long SP, Edwards GE (eds) (1994) Photosynthesis and global changes in the environment. Photosynth Res 39(3):207-495

Olson JM, Amesz J, Ormerod JG, Blankenship RE (eds) (1994) Green and heliobacteria. Photosynth Res 41(1):1-294

\section{3}

Govindjee, Renger G (eds) (1993) How plants and Cyanobacteria make oxygen: 25 years of period four oscillations. Photosynth Res 38(3):211-482

\section{2}

Hartman H (Ed) (1992) Photosynthesis and the origin of life. Photosynth Res 33(2):73-176

Rich PR (ed) (1992) Robin Hill. Photosynth Res 34(3):319-488

\section{9}

Blankenship RE, Amesz J, Holten D, Jortner J (eds) (1989) Tunneling processes in photosynthesis. Part 1. Photosynth Res 22(1):1-122

\section{8}

Govindjee, Bohnert HJ, Bottomley W, Bryant DA, Mullet JE, Ogren WL, Pakrasi H, Somerville CR (eds) (1988) Molecular biology of photosynthesis 1 . Photosynth Res 16(1-2):5-186

Govindjee, Bohnert HJ, Bottomley W, Bryant DA, Mullet JE, Ogren WL, Pakrasi H, Somerville CR (eds) (1988) Molecular biology of photosynthesis 2 . Photosynth Res 17(1-2):5-194

Govindjee, Bohnert HJ, Bottomley W, Bryant DA, Mullet JE, Ogren WL, Pakrasi H, Somerville CR (eds) (1988) Molecular biology of photosynthesis 3. Photosynth Res 18(1-2):5-262

Govindjee, Bohnert HJ, Bottomley W, Bryant DA, Mullet JE, Ogren WL, Pakrasi H, Somerville CR (eds) (1988) Molecular biology of photosynthesis 4. Photosynth Res 19(1-2):5-204

\section{6}

Amesz J, Hoff AJ, van Gorkom HJ (eds) (1986) Double special issue dedicated to Professor Louis NM Duysens on the occasion of his retirement. Photosynth Res 9(1-2):vii+1-283

\section{Conferences}

\section{8}

Prasil O, Suggett DJ, Cullen JJ, Babin M, Govindjee (2008) Aquafluo 2007: chlorophyll fluorescence in aquatic sciences, an international conference held in Nové Hrady. Photosynth Res 95(1):111-115

\section{7}

Blankenship RE (2007) 2007 Awards of the International Society of Photosynthesis Research (ISPR). Photosynth Res 94(2-3):179-181

Govindjee, Telfer A (2007) Six young research investigators were honored at an international conference in Russia. Photosynth Res 92(1):139-141 
Govindjee, Yoo H (2007) The International Society of Photosynthesis Research (ISPR) and its associated international congress on photosynthesis (ICP): a pictorial report. Photosynth Res 91(2-3):95-106

Govindjee, Rutherford AW, Britt RD (2007) Four young research investigators were honored at the 2006 Gordon research conference on photosynthesis. Photosynth Res 92(1):137-138

2006

Aro EM, Golbeck JH, Osmond B (2006) Message from the International Society of Photosynthesis Research (ISPR). Photosynth Res 89(1):7-9

Foyer CH (2006) Photosynthesis coming of age to meet the needs of the 21st century: an invitation to the 14th international congress on photosynthesis research in 2007. Photosynth Res 89(1):3-6

Govindjee, Knaff D (2006) International photosynthesis congresses (1968-2007). Photosynth Res 89(1):1-2

\section{4}

Govindjee (2004) A list of photosynthesis conferences and of edited books in photosynthesis. Photosynth Res 80(1-3):447-460
Rurainski HJ (2004) The conference at Airlie House in 1963. Photosynth Res 80(1-3):439-446

\section{3}

Govindjee, Beatty JT, Gest H (eds) (2003) Celebrating the Golden jubilee of the 1952 conference of photosynthesis (Gatlinburg, Tennessee, USA). Photosynth Res 76(1-3): see a photograph, p. vii

\section{7}

Renger G (1987) Conference report on the Japan/USbinational seminar on "energy conversion: photochemical reaction centers and oxygen evolving complexes of plant photosynthesis." Photosynth Res 13(3):261-268

Acknowledgments I thank Vanessa Conrad for typing this text, and I am grateful to Feng Sheng Hu, Head of Plant Biology, University of Illinois, for his support. 